\section{Blooming time of some apricot varieties of different origin in Hungary}

\author{
Szalay, L. ${ }^{1}$ and Szabó, Z. ${ }^{2}$ \\ ${ }^{I}$ University of Horticulture and Food Industry \\ H-1118 Budapest, Villányi út 35-43. \\ ${ }^{2}$ DATE, College of Agriculture \\ H-5541 Szarvas, Szabadság u. 1-3.
}

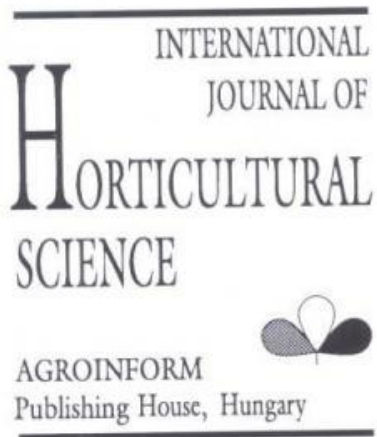

Key words: apricot varieties, blooming time

Summary:There are a number of self-incompatible and partially self-compatible apricot varieties which need cross pollination for suitable Sield. We have to know their blooming time to select the appropriate pollen donor cultivars. The blooming period of 20 apricot varieties was observed in four subsequent years. Blooming time was affected by temperature conditions very much. Varieties studied were assigned to three groups according to their blooming time. The rate of overlapping of important variety combinations was observed. Sufficient overlapping of blooming period for safe pollination is usually ensured within the same group of varieties or between varieties of the neighbouring blooming time groups.

\section{Introduction}

There are a number of self incompatible and partially self compatible ones among apricot cultivars (Nyéki 1990, Szabó and Nyéki 1992, Nyéki and Szabó 1997, Nyéki et al. 1997). Pollen donor trees are essential for self incompatible cultivars, but cross pollination improves also the productivity of self-compatible apricot varieties (Nyéki 1989, Szabó and Nyéki 1992, Benedek et al. 1991,1995).

It is necessary to know the blooming time of varieties for selecting the most suitable pollen donor partners. It is of interest to know the compatible conditions, but incompatibility is not as critical in apricot as in cherry or apple. Interincompatible combinations were described by Szabó and Nyéki (1992) and Burgos et al. (1997).

In this report, results of studies concerning blooming time of 20 apricot cultivars in Hungary are presented. The cultivars involved are introduced from different parts of the world.

Apricot is one of earliest blooming fruit species in Hungary, starting between the end of February and the end of April, depending on the season. Nyujtó (1980) states that the first fowers bloom as a mean of many years between 8 and 13 April. The average of the last years shifted to earlier dates by 2 to 10 days. Pedryc (1992) stated that the first flowers appeard in the last 6 years between March 11 and April 7.

In Hungary, near to the northern border of apricot production, there is little difference in flowering dates, about 4-5 days in the main varieties. Taking in account larger assortments and cool spring weather, the time of start in blooming may be extended to 8-12 days (Nyujtó 1980, Pedryc 1992).

\section{Material and methods}

Blooming time of 20 apricot varieties was observed from 1994 to 1997 at Szigetcsép. We observed 4 trees per variety. Trees have been grafts on cherry plum stocks ( $P$. cerasifera var: myrabolan) in the collection of the University. Blooming rate was estimated by visual observation every second day at noon during the blooming period. Blooming dynamics are presented in a histogram and the day when the peak of blooming ensued was marked. Varieties were classified into 3 groups according to their blooming time. Mutual overlapping of the blooming time of varieties was registered.

\section{Results and discussion}

Data on temperature are represented in Figure 3, 4, 5, 6 and blooming periods of varieties from 1994 to 1997 in Figure $7,8,9,10$. Blooming time was affected by temperatures during the winter and early spring, however, there were considerable differences between years in blooming time and dynamics. Blooming period started as the earliest in 1994, March 19. In 1995 and 1997 blooming on the last days of March. In the three years mentioned above the blooming period was long, whereas in 1996 the blooming started extremely late, April 19, and was very fast, because of the warm weather.

Under warmer climate, the differences in blooming time tend to be much more important. Della Strada et al. (1989) reports in Central Italy that one month elapsed in the start of blooming between the first and last varieties: February 15 (Mech Mech Precoce) and March 19 (Stella). 

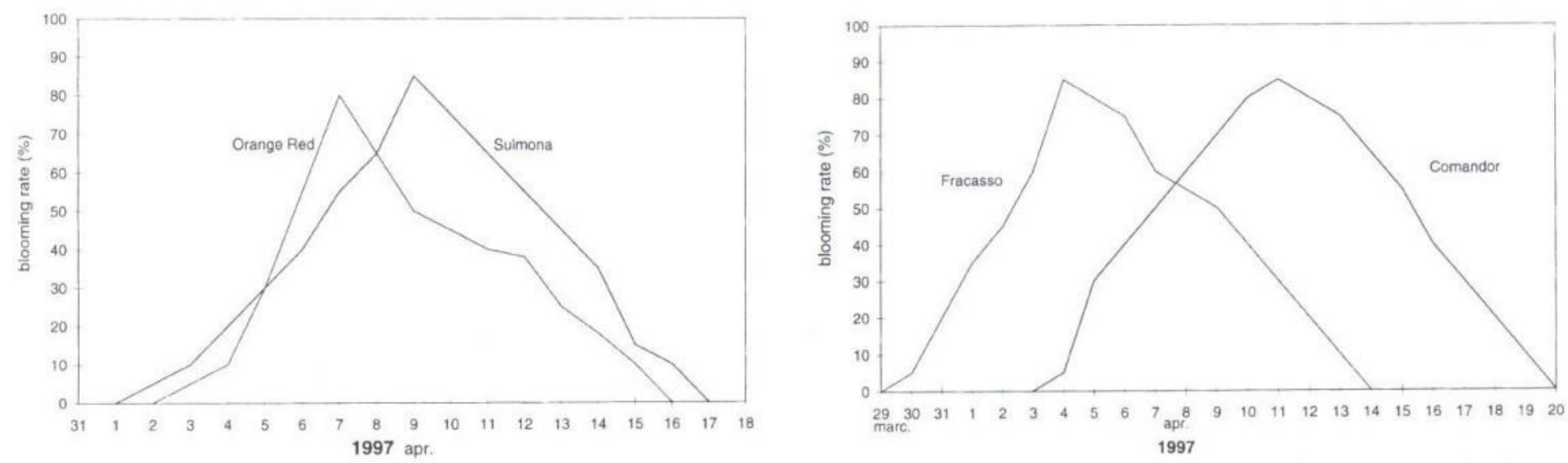

Figure 1 and 2 Bluming intensity and overlap of varieties.
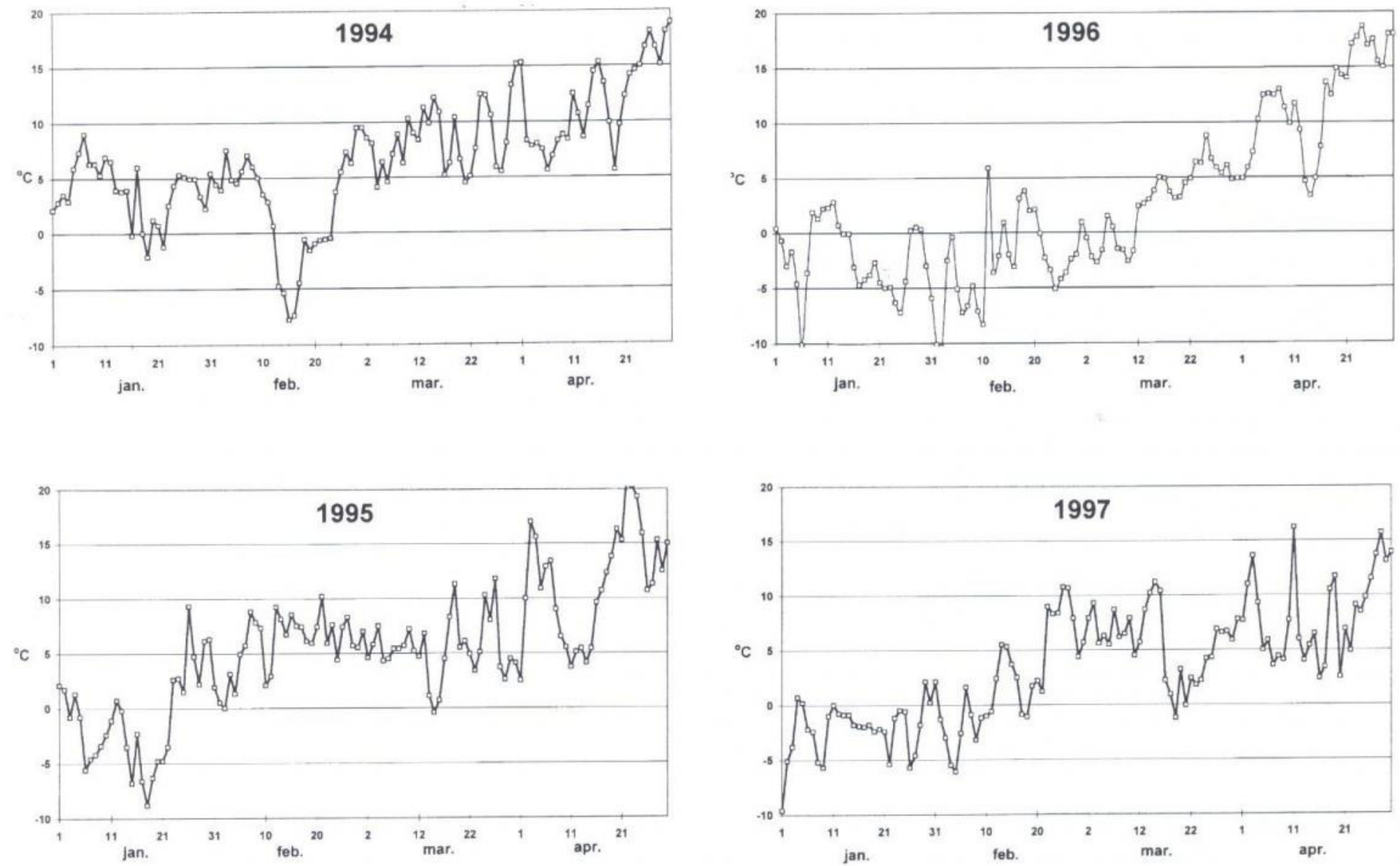

Figures 3 to 6 Daily mean temperatures of four subsequent years

The length of the blooming period was equally very variable depending on the season, in Hungary. The 20 varieties observed bloomed during 5-7 days in a warm weather, whereas 14-21 days at low temperatures. The length of the blooming period was inversely related to the date of start. Nyujtó (1980) found also as short periods as 5 days. Magyar kajszi bloomed at $20^{\circ} \mathrm{C}$ for $6-7$ days, at $15-20^{\circ} \mathrm{C}$ for 8-11 days, at $12-15^{\circ} \mathrm{C}$ for as many as $11-16$ days (Surányi \& Molnár 1981).

On the basis of the observations, varieties were classified to three groups (Table 2.) Blooming time of Orange Red and Rosé Fournés was fluctuating compared with the other varieties. 
Table 1 Blooming period of apricot varieties (Szigetcsép, 1994-1997)

\begin{tabular}{l|c|c|c|c|c|c|c|c|c|c}
\hline \multirow{2}{*}{ \#ariety } & \multicolumn{2}{|c|}{1994} & \multicolumn{1}{c|}{1995} & \multicolumn{2}{c|}{1996} & \multicolumn{2}{c|}{1997} & \multicolumn{2}{c}{ Mean } \\
\cline { 2 - 10 } & $\mathrm{D}$ & $\mathrm{L}$ & $\mathrm{D}$ & $\mathrm{L}$ & $\mathrm{D}$ & $\mathrm{L}$ & $\mathrm{D}$ & $\mathrm{L}$ & $\mathrm{D}$ & $\mathrm{L}$ \\
\hline Callatis & 0 & 16 & 2 & 18 & 1 & 7 & 3 & 15 & 1,5 & 14 \\
Comanịor & 0 & 17 & 2 & 17 & 1 & 7 & 3 & 16 & 1,5 & 14,25 \\
Fracasso & 1 & 16 & 2 & 16 & 0 & 6 & -2 & 15 & 0,25 & 13,25 \\
Gönci m. k. & $*$ & 15 & $* *$ & 16 & $* * *$ & 7 & $* * * *$ & 12 & $* * * * *$ & 12,5 \\
Harlayne & 0 & 16 & 0 & 19 & -1 & 8 & 1 & 10 & 0 & 13,25 \\
Harglow & 1 & 19 & 3 & 16 & 2 & 5 & 5 & 13 & 2,75 & 13,25 \\
Hargrand & 0 & 16 & 2 & 16 & 0 & 6 & 5 & 13 & 1,75 & 12,25 \\
Harogem & 1 & 21 & 0 & 17 & 0 & 6 & 3 & 14 & 1 & 14,5 \\
HW 409 & 0 & 16 & 1 & 15 & 0 & 6 & 2 & 13 & 0,75 & 12,5 \\
Lamb. Nol & 0 & 14 & 1 & 15 & -1 & 6 & 0 & 14 & 0 & 12,25 \\
Latter Sabatini & 0 & 16 & 0 & 16 & -1 & 6 & -1 & 7 & $-0,5$ & 11,25 \\
Litoral & 0 & 16 & 1 & 15 & 2 & 5 & -1 & 15 & 0,5 & 12,75 \\
Mamaya & 2 & 15 & 5 & 15 & 2 & 6 & 3 & 14 & 3 & 12,5 \\
Mandulakajszi & 4 & 17 & 4 & 17 & 2 & 7 & 2 & 14 & 3 & 13,75 \\
Orange Red & 0 & 18 & 5 & 13 & 1 & 6 & 2 & 13 & 2 & 12,5 \\
Pannónia & 0 & 14 & 0 & 16 & 1 & 7 & 1 & 13 & 0,5 & 12,5 \\
Rosé Fournés & 0 & 18 & 0 & 20 & 0 & 5 & -2 & 16 & $-0,5$ & 14,75 \\
Selena & 1 & 16 & 1 & 17 & 1 & 7 & 3 & 16 & 1,5 & 14 \\
Sirena & 1 & 16 & 2 & 19 & 2 & 6 & 3 & 15 & 2 & 14 \\
Sulmona & 2 & 14 & 2 & 10 & 2 & 5 & 1 & 15 & 1,75 & 11 \\
\hline
\end{tabular}

\#D Deviation from the blooming time of Gönci magyar kajszi (+/- days) as standard

$\mathrm{L}$ Length of the blooming period in days

$$
\begin{array}{llll}
* & \text { March 18. } & 1994 & \text { start of blooming of Gönci m.k. } \\
* * & \text { March 28. } & 1995 & * \\
* * * & \text { April 19. } & 1996 & . \\
* * * * & \text { April 1. } & 1997 & . \\
* * * * * & \text { April 2. } & \text { Mean of 4 year } . *
\end{array}
$$

Della Strada et al. (1989) found differences of more than one month between the flowering time in a series of many varieties, which were assigned to 5 groups. In our sample, 3 groups were justified, only.

According to the literature Orange Red, Harcot and Lambertini No $I$ are absolutely self-incompatible (Burgos et al.
Table 2 Classification of apricot varieties according to their blooming time (Szigetcsép 1994-1997)

\begin{tabular}{l|l|l}
\hline early bloom & intermediate bloom & late bloom \\
\hline Fracasso & Callatis & Harglow \\
Gönci magyar kajszi & Comandor & Harogem \\
Harlayne & Hargrand & Mamaia \\
HW 409 & Orange Red & Mandulakajszi \\
Lambertin Nol & Rosé Fournes & Sirena \\
Latter Sabatini & Selena & \\
Litoral & Sulmona & \\
Pannónia & & \\
\hline
\end{tabular}

1997), Litoral, Comandor; Sulmona and Mandulakajszi are partially compatible (Pedryc et al. 1993, Szalay 1997). They need a pollinizer, so we observed the rate of overlapping in blooming times of these varieties with others (Table 3). The data of 1996 were ignored because of the very fast blooming in this year.

In Hungary, near to the northern border of apricot production the coincidence of blooming has much more chances especially when the spring weather is of the continental type, i.e. short, like in 1996. Moreover, on the average, more than $50 \%$ of blooming time overlapped in a system of the 7 important and 20 pollinizer varieties, being 53 to $99 \%$ in pairs taken individually. For good pollination at least $70 \%$ overlapping in blooming periods is necessary which is ensured between varieties of the same or neighbouring blooming time group (Szabó \& Nyéki, 1992). They called our attention to the necessity of planting more than one pollinizer variety for a target variety. So there is a comparison of overlap in Table 3.

Della Strada et al. (1989) and Pirazzini (1997) observed the blooming of apricots in the Mediterranean area. There, no possibility of natural cross pollination exists between early and late blooming varieties because the lack of overlap.

In Figure 1-2, two examples are presented with varieties representing a sufficient and a poor overlap in blooming in the year 1997. The graph shows the rate of open flowers ready for pollination or to be pollinated. Thus Orange Red and Sulmona showed coincidence whereas Fracasso and Comandor did it much less.

Table 3 Overlap of blooming period of apricot varieties (\%)

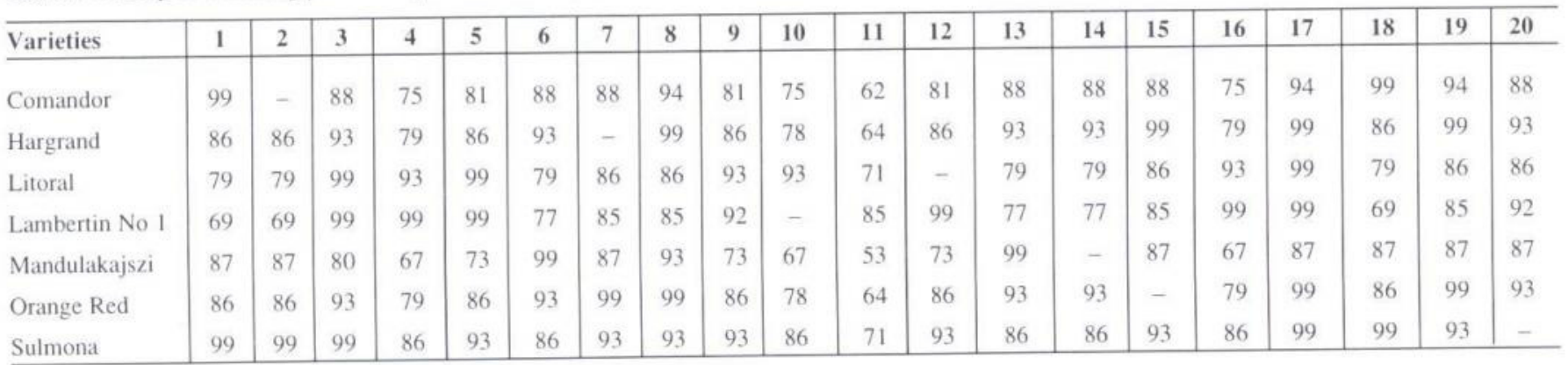

Pollinizer varieties: I Callatis, 2 Comandor, 3 Fracasso, 4 Gönci magyar kajszi, 5 Harlayne, 6 Harglow, 7 Hargrand, 8 Harogem, 9 HW 409, 10 Lamberti No 1. 11 Latter Sabatini, 12. Litoral, 13 Mamaia, 14 Mandulakajszi, 15 Orange Red, 16 Pannónia, 17 Rosé Fournés, 18 Selena, 19 Sirena, 20 Sulmona 


\begin{tabular}{l|l|l|l|l|l|l|l|l|l|l|l|l|l}
\hline \multirow{2}{*}{ Variety } & \multicolumn{10}{c|}{1994} & \multicolumn{7}{c}{ March } & \multicolumn{7}{c}{ April } \\
\hline & 18 & 20 & 22 & 24 & 26 & 28 & 30 & 2 & 4 & 6 & 8 & 10 & 12 \\
\hline Callatis & & & & & & & & & & & & & \\
\hline Comandor & & & & & & & & & & & & & \\
\hline Fracasso & & & & & & & & & & & & & \\
\hline Gönci m.k. & & & & & & & & & & & & & \\
\hline Harlayne & & & & & & & & & & & \\
\hline Harglow & & & & & & & & & & & \\
\hline Hargrand & & & & & & & & & & & & \\
\hline Harogem & & & & & & & & & & & & \\
\hline HW 409 & & & & & & & & & & & & & \\
\hline Lambertin & & & & & & & & & & & & \\
\hline Latter Sab & & & & & & & & & & & & & \\
\hline Litoral & & & & & & & & & & & & \\
\hline Mamaia & & & & & & & & & & & & \\
\hline Mandulak. & & & & & & & & & & & & \\
\hline Orange Red & & & & & & & & & & & & \\
\hline Pannónia & & & & & & & & & & & & \\
\hline Rose Four & & & & & & & & & & & & \\
\hline Selena & & & & & & & & & & & \\
\hline Sirena & & & & & & & & & & \\
\hline Sulmona & & & & & & & & & & & \\
\hline
\end{tabular}

\begin{tabular}{|c|c|c|c|c|c|c|c|c|c|c|c|c|}
\hline \multirow[b]{3}{*}{ Variety } & & & & & & \multicolumn{6}{|c|}{1996} & \\
\hline & & & & & & & & & & & & \\
\hline & 6 & 8 & 10 & 12 & 14 & 16 & 18 & 202 & 22.2 & & \begin{tabular}{l|l|l}
26 & 28 \\
\end{tabular} & 30 \\
\hline \multicolumn{13}{|l|}{ Callatis } \\
\hline \multicolumn{13}{|l|}{ Comandor } \\
\hline \multicolumn{13}{|l|}{ Fracasso } \\
\hline \multicolumn{13}{|l|}{ Gönci m.k. } \\
\hline \multicolumn{13}{|l|}{ Harlayne } \\
\hline \multicolumn{13}{|l|}{ Harglow } \\
\hline \multicolumn{13}{|l|}{ Hargrand } \\
\hline \multicolumn{13}{|l|}{ Harogem } \\
\hline \multicolumn{13}{|l|}{ HW 409} \\
\hline \multicolumn{13}{|l|}{ Lambertin } \\
\hline \multicolumn{13}{|l|}{ Latter Sab } \\
\hline \multicolumn{13}{|l|}{ Litoral } \\
\hline \multicolumn{13}{|l|}{ Mamaia } \\
\hline \multicolumn{13}{|c|}{ Mandulak. } \\
\hline \multicolumn{13}{|c|}{ Orange Red } \\
\hline \multicolumn{13}{|l|}{ Pannónia } \\
\hline \multicolumn{13}{|l|}{ Rose Four } \\
\hline \multicolumn{13}{|l|}{ Selena } \\
\hline \multicolumn{13}{|l|}{ Sirena } \\
\hline Sulmona & & & & & & & & & & & & \\
\hline
\end{tabular}

1995

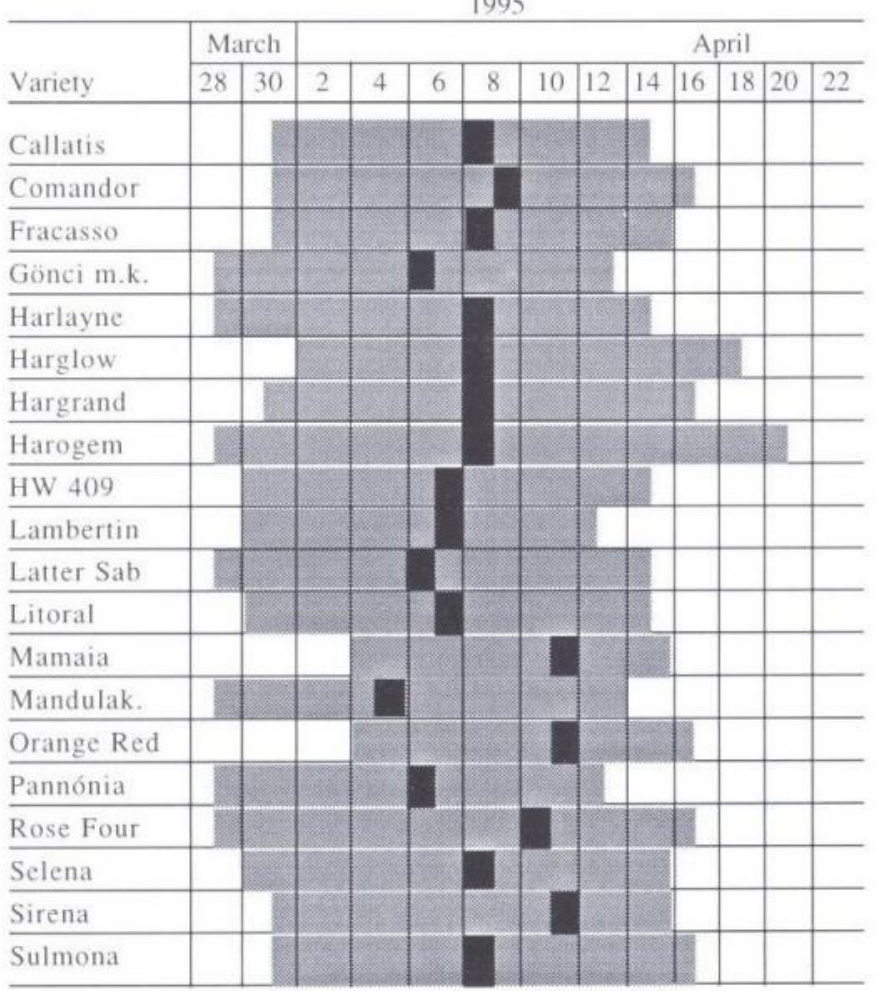

1997

\begin{tabular}{|c|c|c|c|c|c|c|c|c|c|c|c|c|c|}
\hline \multirow[b]{2}{*}{ Variety } & \multicolumn{2}{|c|}{ March } & \multicolumn{11}{|c|}{ April } \\
\hline & 28 & 30 & 2 & 4 & 6 & 8 & 10 & 12 & 14 & 16 & 18 & 20 & 22 \\
\hline \multicolumn{14}{|l|}{ Callatis } \\
\hline \multicolumn{14}{|l|}{ Comandor } \\
\hline \multicolumn{14}{|c|}{ Fracasso } \\
\hline \multicolumn{14}{|c|}{ Gönci m.k. } \\
\hline \multicolumn{14}{|c|}{ Harlayne } \\
\hline \multicolumn{14}{|l|}{ Harglow } \\
\hline \multicolumn{14}{|l|}{ Hargrand } \\
\hline \multicolumn{14}{|l|}{ Harogem } \\
\hline \multicolumn{14}{|l|}{ HW 409} \\
\hline \multicolumn{14}{|c|}{ Lambertin } \\
\hline \multicolumn{14}{|l|}{ Latter Sab } \\
\hline \multicolumn{14}{|c|}{ Litoral } \\
\hline \multicolumn{14}{|c|}{ Mamaia } \\
\hline \multicolumn{14}{|c|}{ Mandulak. } \\
\hline \multicolumn{14}{|c|}{ Orange Red } \\
\hline \multicolumn{14}{|c|}{ Pannónia } \\
\hline \multicolumn{14}{|l|}{ Rose Four } \\
\hline \multicolumn{14}{|l|}{ Selena } \\
\hline \multicolumn{14}{|l|}{ Sirena } \\
\hline Sulmona & & & & & & & & & & & & & \\
\hline
\end{tabular}

Figure 7 Blooming dynamics of 20 apricof varieties in 1994-1997

\section{References}

Benedek P.-Nyéki J.-Szabó Z. (1991): Properties of apricot varieties which affect the attractivity of flowers in bee pollination. (Hungarian) Kertgazdaság. 23(2): 27-39.
Benedek P.-Nyéki J.-Szabó Z. (1995): Bee pollination of apricot: variety features affecting bee activity. Acta Horticulturae 384 : 329-332. 
Burgos, L.-Egea, J.-Guerriero, R.-Viti, R.-Monteleone, P.-Audergon, J.M. (1997): The self-compatibility trait of the main apricot cultivars and new selections from breeding programmes. Journal of Hort. Sci. 72 (1) 147-154.

Nyéki J. (1990): Flowering, pollination and fertility of fruit crops.(Hungarian) In: Gyuró F. (ed.): Gyümölcstermesztés. Mezōgazdasági Kiadó. Budapest.

Nyéki J. (1989): Flowering and fertility of stone fruits. (Hungarian) Thesis of Habilitation, Budapest.

Nyéki J. (ed.) (1980): Flowering and fertility of fruit species. (Hungarian) Mezổgazdasági Kiadó. Budapest.

Nyéki J.-Szabó Z. (1997): Cross incompatibility in stone fruits. Acta Horticulturae 437:213-217.

Nyéki J.-Szabó Z.-Andrásfalvy A.-Erdōs Z. (1997): Morphological and phenological properties of giant (.,óriás”) type apricot varieties and their fertility relations. Acta Horticulturae (in press).
Nyujtó F. (1980): The apricot. In. Nyéki J. (ed.) Flowering biology and fertility of fruit varieties. Mezổgazdasági Kiadó. Bp.

Peryć, A. (1992): Variability of some features of apricot varieties according to breading. Ph. D. thesis. MTA. Budapest.

Pedryć, A.-Szabó Z.-Nyéki J.-Davary-Nejad G. H. (1993): Production and market value of Rumanian apricot varieties. (Hungarian), Kertgazdaság. 25(1): 38-45.

Piazzini, P. (1997): Prove di impollinazione su nouve cultivar di albicocco nell Imolese. Italus Hortus 4(2): 70-71.

Szabó Z.-Nyéki J. (1992): Blossoming, fertilisation and associated placing of apricot varieties. Acta Horticulturae 293: 295-302.

Szalay L. (1997): Acclimation of apricot varieties of late ripening season (Hungarian). KÉE Budapest. Diplomamunka. 